Zeszyty Naukowe Szkoły Głównej Gospodarstwa Wiejskiego w Warszawie

Problemy Rolnictwa Światowego tom 18 (XXXIII), zeszyt 1, 2018: 23-37

DOI: $10.22630 /$ PRS.2018.18.1.2

Iwona M. Batyk $^{1}$

Uniwersytet Warmińsko-Mazurski w Olsztynie

\title{
Zmiany w polskim handlu zagranicznym produktami rolno-spożywczymi z Federacją Rosyjską w latach 2006-2015
}

\section{Changes in Polish Foreign Trade in Agri-Food Products with the Russian Federation in 2006-2015}

\begin{abstract}
Synopsis. Celem artykułu jest wskazanie najważniejszych zmian w polskim handlu zagranicznym produktami rolno-spożywczymi z Federacją Rosyjską w latach 2006-2015. Do weryfikacji celu wykorzystano analizę zmian w czasie oraz analizę struktury handlu zagranicznego produktami rolnospożywczymi w latach 2006-2015. Artykuł jest wynikiem analizy literatury i opracowań statystycznych. Zastosowane dane pochodzą z Roczników Statystycznych Handlu Zagranicznego. Wymianę handlową towarami rolno-spożywczymi charakteryzuje znaczna przewaga eksportu z Polski do Rosji nad importem. Wartość obrotów istotnie zmniejszyła się po wprowadzeniu w 2014 r. przez Federację Rosyjską ograniczeń w imporcie tych produktów z krajów Unii Europejskiej. Dynamika eksportu do Rosji zależna była od kategorii towarów. Największe zmiany dotyczyły produktów pochodzenia roślinnego i zwierzęcego, ponieważ ich eksport obarczony był wysokim stopniem barier handlowych, wynikających przede wszystkim z sytuacji geopolitycznej. Do poprawy polskorosyjskich relacji gospodarczych i handlowych konieczna jest akceptacja przez Rosję norm unijnych na produkcję oraz certyfikację weterynaryjną i fitosanitarną produktów rolno-spożywczych.
\end{abstract}

Slowa kluczowe: Rosja, handel zagraniczny, produkty rolno-spożywcze, embargo

\begin{abstract}
The aim of the article is to identify the most important changes in Polish foreign trade in agri-food products with the Russian Federation in the years 2006-2015. To verify these shifts, changes over time and the structure of foreign trade in agri-food products in 2006-2015 were analyzed. The value of Poland's foreign trade turnover with Russia, the turnover balance and the share of agri-food products in trade were presented. The value of imports and exports in the categories of agri-food product groups and the dynamics of the import and export of agri-food products was also presented. The article is the result of the analysis of literature and statistical studies. Data from the Statistical Yearbook of Foreign Trade was used. Trade exchange of agri-food products is characterized by an advantage of exports from Poland to Russia. The value of trading these products was reduced after the restrictions of the Russian Federation in 2014 on the import of these products from the EU. The dynamics of exports to Russia were dependent on the category of products. The most significant changes were related to products of plant and animal origin, because their exports depended on trade barriers resulting from the geopolitical situation. To improve Polish-Russian economic and trade relations, Russia must accept EU standards for the production and veterinary and phytosanitary certification of agri-food products.
\end{abstract}

Key words: Russian Federation, foreign trade, agri-food products, embargo

JEL Classification: F10, F40, F51

\footnotetext{
${ }^{1}$ dr inż., Wydział Nauk Ekonomicznych UW-M w Olsztynie, ul. M. Oczapowskiego 4, 10-719 Olsztyn, e-mail: iwona.batyk@uwm.edu.pl
} 


\section{Wprowadzenie}

Federacja Rosyjska pod względem geopolitycznym odgrywa strategiczną rolę, zarówno na poziomie globalnym, jak i regionalnym. Należy ona do najważniejszych partnerów handlowych Polski. Z uwagi na uwarunkowania gospodarcze i społeczne oraz położenie geograficzne, dostępność do rynku rosyjskiego jest bardzo istotna dla regionów objętych europejską polityką sąsiedztwa. Rynek ten charakteryzuje się dużą dynamiką rozwoju i posiada potencjał, który można wykorzystać dla osiągnięcia korzyści w zakresie rozwoju współpracy gospodarczej.

Polska i Rosja różnią się istotnie pod względem potencjałów gospodarczych i produkcyjnych. Asymetria dotyczy protekcji rynków dostaw i rynków zbytu. Zdecydowana większość wymiany handlowej Polski i Rosji koncentruje się w sektorach, które charakteryzuje niski stopień barier handlowych oraz zgodność systemów regulacyjnych. Znacząca asymetria w polsko-rosyjskich obrotach handlowych zaznacza się w sektorze surowców energetycznych oraz w sektorze rolno-spożywczym. W pierwszym występują wyraźne dysproporcje importu nad eksportem na niekorzyść Polski, zaś w drugim - eksportu nad importem na niekorzyść Rosji. W strukturze towarowej importu z Rosji dominuja produkty mineralne, przede wszystkim dostawy ropy naftowej i gazu ziemnego oraz rudy żelaza, których udział w 2006 r. stanowił 84\% (GUS, 2007). Wielkość importu tych produktów w handlu z Rosją od kilku lat pozostaje na zbliżonym poziomie. Rosyjskie produkty rolno-spożywcze ze względu na niskie standardy jakości, nie są konkurencyjne na rynku polskim, natomiast polska żywność stanowi dużą konkurencję zarówno w zakresie jakości jak i ceny dla produktów pochodzących z rynku rosyjskiego (Batyk, 2014).

Sektor rolnictwa uznawany jest jako objęty najwyższą protekcją sektor gospodarek narodowych, najbardziej niezdyscyplinowany obszar handlu międzynarodowego i przyczyna największych konfliktów w międzynarodowych stosunkach gospodarczych (McCalla, 1993, s. 1102-1112). Grant i Lambert (2008) dowiedli, że w liberalizowaniu wymiany artykułami rolnymi, skuteczniejsze od traktatów i rozporządzeń Światowej Organizacji Handlu były regionalne porozumienia handlowe (Grant i Lambert, 2008).

Polsko-rosyjska wymiana handlowa produktami rolno-spożywczymi w skali makroekonomicznej oraz na poziomie sektorowym, zdeterminowana jest obowiązującymi sankcjami. Wprowadzenie przez Federację Rosyjską znacznych ograniczeń w imporcie artykułów rolno-spożywczych z krajów UE, spowodowało diametralną zmianę warunków wymiany handlowej oraz zasad konkurowania, zarówno na rynkach regionalnych, jak i rynku światowym. W sposób szczególny zmiana sytuacji konkurencyjnej dotyczy producentów i eksporterów artykułów rolno-spożywczych.

Celem artykułu jest wskazanie najważniejszych zmian $w$ polskim handlu zagranicznym produktami rolno-spożywczymi z Federacją Rosyjską w latach 2006-2015, ze szczególnym uwzględnieniem zmian jakie nastąpiły po 2011 r. Do weryfikacji celu wykorzystano analizę zmian w czasie oraz analizę struktury handlu zagranicznego. Tematyka bilateralnych powiązań gospodarczych dotyczących sektora rolno-spożywczego jest istotna dla podmiotów działających w tym sektorze. Informacje prezentowane w artykule moga być pomocne dla indywidualnych producentów i przetwórców w profilowaniu dalszej ich działalności i poszukiwaniu partnerów do wymiany handlowej. Wiedza z zakresu powiązań gospodarczych stanowić powinna także wsparcie dla opracowania rekomendacji dla polityki gospodarczej państwa. Nabiera ona tym większego 
znaczenia $\mathrm{w}$ perspektywie planów idziałań podmiotów agrobiznesu w warunkach istniejącego ryzyka politycznego, które w istotny sposób oddziaływuje na rynki dostaw i rynki zbytu. Ograniczenia w handlu mogą być wykorzystywane nie tylko do ochrony konsumentów czy przetwórców (Wiśniewska, 2011). Mogą stanowić także instrument polityki zagranicznej o charakterze represyjnym czy prewencyjnym, np. po wprowadzeniu embarga przez Rosję, przewidywano, że może przyczynić się ono do znacznego ograniczenia polskiego eksportu produktów wieprzowych, ze względu na relatywnie duży udział eksportu do Rosji produktów wieprzowych eksportowanych z UE (Pasińska, 2017).

\section{Uwarunkowania polsko-rosyjskiej wymiany handlowej}

Po głębokiej recesji gospodarczej w 1998 r., w wyniku tzw. kryzysu rosyjskiego, w kolejnych latach gospodarka Rosji odbudowywała się w szybkim tempie. Przed rozszerzeniem Unii Europejskiej, Rosja dość nieprzychylnie oceniała możliwe skutki dla polsko-rosyjskiej wymiany handlowej. W perspektywie dostępu towarów rosyjskich na rynki krajów członkowskich Wspólnoty Europejskiej, jako konsekwencji obowiązywania w tych krajach „Porozumienia o partnerstwie i współpracy między Federacją Rosyjską a UE”, Rosja liczyła na poprawę warunków handlowych. Jednocześnie, wyrażała obawy związane $\mathrm{z}$ dużymi stratami $\mathrm{w}$ obrocie handlowym $\mathrm{z}$ nowymi krajami członkowskimi. Obawy te były uzasadnione, ponieważ udział krajów Europy Środkowo-Wschodniej (w tym Polski) w rosyjskim eksporcie wzrastał od połowy lat 90-tych XX wieku, natomiast w przypadku importu tendencja była odwrotna.

Przystapienie Polski do Unii Europejskiej wywołało zmiany warunków polskorosyjskiej wymiany handlowej. Wzajemne stosunki gospodarcze uległy radykalnym zmianom zarówno politycznym, jak również formalno-prawnym i organizacyjnym. W obrotach gospodarczych z Rosją dominuje handel towarami. Międzynarodowy obrót towarowy podlega regulacjom celnym. Założeniem polityki celnej jest kształtowanie korzystnych warunków dla tworzenia i zabezpieczania konkurencyjności oraz pomnażania wartości przedsiębiorstw (Czyżowicz, 2009). Niestety polityka celna Rosji w wielu obszarach znacząco ograniczyła eksport polskich towarów, co mogło być związane z obawami przed stratami dla rosyjskiego handlu, wynikającymi z przyjęcia przez Polskę wymogów unijnych. Wymogi te znacznie podwyższyły standardy i normy na wiele produktów eksportowanych do Rosji. Podniesiony poziom wymagań stanowi istotną barierę dla towarów rosyjskich, co dotyczy głównie eksportu towarów rolno-spożywczych oraz maszyn i wyrobów przemysłu chemicznego.

Zaostrzenie przez Rosje norm weterynaryjnych i fitosanitarnych stało się barierą pozataryfową $\mathrm{w}$ imporcie towarów $\mathrm{z}$ krajów UE. Podawaną przez Rosję oficjalną przyczyną wprowadzenia zakazów w imporcie towarów rolno-spożywczych z Polski, była konieczność ochrony rosyjskich konsumentów. Jednakże dość powszechnie uważa się, że ograniczenia w imporcie były przede wszystkim instrumentem realizacji celów politycznych. Potwierdzeniem tego były wyniki kontroli jakości produktów rolnospożywczych sprzedawanych na rynku rosyjskim, które wykazały, że zakazy przywozu niejednokrotnie dotyczyły towarów, których produkcja krajowa miała wyraźnie niższą jakość niż produkty importowane, np. mięsa (Błaszczuk-Zawiła, 2014).

W latach 2004-2007 w dynamicznie rozwijającej się gospodarce rosyjskiej odnotowano średnie tempo wzrostu PKB na poziomie 7,6\%. Kryzys gospodarczy w latach 
2008-2009 spowodował spowolnienie wzrostu gospodarczego. Dalszy spadek nastapił w 2009 r. i był skutkiem zarówno kryzysu finansowego, jak i spadku światowych cen surowców energetycznych. Odbudowa aktywności gospodarczej po kryzysie z lat 20082009 była wolniejsza niż ta sprzed dziesięciu lat (Współpraca..., 2014). Pomimo wzrostu i utrzymywania się na wysokim poziomie światowych cen ropy naftowej i gazu ziemnego, surowców uważanych za siłę napędową rosyjskiej gospodarki, odnotowano słabszą dynamikę wzrostu gospodarczego. Kryzys finansowy miał istotny wpływ na zachowania konsumentów rosyjskich, powodując przekierowanie zainteresowania na towary pochodzenia zagranicznego.

Ponowne spowolnienie rosyjskiej gospodarki nastapiło od 2012 r. i wynikało przede wszystkim ze spadku cen ropy naftowej. Od 2014 r. odczuwalne są w Rosji skutki kryzysu ukraińsko-rosyjskiego, tj. spadek inwestycji, wycofanie zagranicznego kapitału oraz deprecjacja rubla i zaburzenia na rosyjskim rynku finansowym. Skutkiem konfliktu ukraińsko-rosyjskiego i dynamicznie zmieniających się uwarunkowań politycznogospodarczych było odwrócenie wzrostowego trendu polskiego eksportu do Rosji, który obniżył się w 2014 r. o $12,9 \%$ w stosunku do roku poprzedniego, co stanowiło $4,4 \%$ udziału w eksporcie ogółem (5,3\% w 2013 r.) (Powiązania..., 2015). Wprowadzenie ograniczeń w handlu spowodowało zmniejszenie eksportu w kierunku wschodnim. Wartość eksportu do Wspólnoty Niepodległych Państw (WNP) w 2014 r. wyniosła 1,7 mld euro, w porównaniu do 2013 r. zmniejszyła się o $22,9 \%$. Sprzedaż do WNP stanowiła 7,9\% wartości całego eksportu towarów rolno-spożywczych i była na znacznie niższym poziomie niż w 2013 r. (10,7\%) (Gospodarcze..., 2014).

\section{Dane i metody}

Celem artykułu jest określenie zmian $\mathrm{w}$ polskim handlu zagranicznym produktami rolno-spożywczymi z Federacją Rosyjską w latach 2006-2015, ze szczególnym uwzględnieniem zmian jakie nastapiły od 2011 r. Źródłem danych do analizy i wnioskowania były informacje pochodzace z Roczników Statystycznych Handlu Zagranicznego. Do prezentacji wyników zastosowano analizę zmian w czasie oraz analize struktury handlu zagranicznego produktami rolno-spożywczymi. Zaprezentowano wartość obrotów handlu zagranicznego Polski z Rosją, saldo obrotów oraz udział towarów rolnospożywczych w wymianie handlowej, a także dynamikę importu i eksportu ogółem oraz towarów rolno-spożywczych. Przedstawiono również wartość importu i eksportu w kategoriach grup produktów rolno-spożywczych. Szczegółowej analizie poddano poszczególne grupy towarów, określono strukturę importu i eksportu produktów rolnospożywczych oraz dynamikę importu i eksportu tych towarów w latach 2011-2015. Zakres czasowy badań został zdeterminowany dostępnością kompletnych i porównywalnych w skali międzynarodowej danych. W układzie kategorii produktów analize przeprowadzono na poziomie sekcji Scalonej Nomenklatury Towarowej Handlu Zagranicznego (Combined Nomenclature - CN). Ze względu na brak danych dotyczących grup asortymentowych w sekcji $\mathrm{CN}$, do szczegółowej analizy struktury i dynamiki importu i eksportu poszczególnych grup towarów, wykorzystano dane gromadzone wg systemu Międzynarodowej Standardowej Klasyfikacji Handlu (SITC). 
Analizę danych przeprowadzono w układzie wertykalnym, pozwalającym na zbadanie struktury analizowanych elementów. Uzyskane wyniki zaprezentowano w postaci tabelarycznej i graficznej.

\section{Wyniki badań}

W latach 2006-2015 polsko-rosyjski handel zagraniczny charakteryzował się dużą zmiennością (tab. 1). Obroty towarowe wzrastały do 2008 r., a w 2009 r. obniżyły się o ponad 39\% w porównaniu do roku poprzedniego. Spadek ten był skutkiem zarówno kryzysu finansowego, jak i obniżki światowych cen surowców energetycznych. Od 2010 do 2012 r. nastapił wzrost wartości obrotów towarowych i zwiększyło się ujemne saldo tych obrotów. Dynamika wzrostu importu w latach 2010-2011 była wyższa od dynamiki wzrostu eksportu. Odwrotną sytuację zanotowano w 2012 r. - import towarów z Rosji wzrósł o 9,5\%, zaś eksport do Rosji zwiększył się o 15,9\%.

Tabela 1. Handel zagraniczny Polski z Rosją w latach 2006-2015

Table 1. Foreign trade between Poland and Russia in 2006-2015

\begin{tabular}{l|cccccc}
\hline \multirow{2}{*}{ Rok } & $\begin{array}{c}\text { Obroty } \\
\text { ogółem } \\
\text { [mln USD] }\end{array}$ & $\begin{array}{c}\text { Import } \\
\text { ogółem } \\
\text { [mln USD] }\end{array}$ & $\begin{array}{c}\text { Import } \\
\text { produktów } \\
\text { rolno- } \\
\text { spożywczych } \\
\text { [mln USD] }\end{array}$ & $\begin{array}{c}\text { Eksport } \\
\text { ogółem } \\
\text { [mln USD] }\end{array}$ & $\begin{array}{c}\text { Eksport } \\
\text { produktów } \\
\text { rolno- } \\
\text { spożywczych } \\
\text { [mln USD] }\end{array}$ & $\begin{array}{c}\text { Bilans } \\
\text { ogółmlem } \\
\text { [mind USD }\end{array}$ \\
\hline 2006 & 16856,1 & 12145,0 & 62,8 & 4711,1 & 541,6 & $-7433,9$ \\
2007 & 20785,0 & 14352,8 & 70,1 & 6432,2 & 619,6 & $-7920,6$ \\
2008 & 29462,3 & 20545,0 & 68,9 & 8917,3 & 706,2 & $-11627,7$ \\
2009 & 17849,5 & 12834,4 & 49,3 & 5015,1 & 778,3 & $-7819,3$ \\
2010 & 24823,8 & 18205,9 & 58,7 & 6617,9 & 992,5 & $-11588,0$ \\
2011 & 34066,0 & 25534,5 & 86,2 & 8531,5 & 1114,4 & $-17003,0$ \\
2012 & 37854,0 & 27964,5 & 91,6 & 9889,5 & 1357,3 & $-18075,0$ \\
2013 & 36070,5 & 25265,2 & 119,5 & 10805,3 & 1668,7 & $-14459,9$ \\
2014 & 32834,0 & 23420,0 & 216,4 & 9414,0 & 1192,2 & $-14006,0$ \\
2015 & 20065,6 & 14371,8 & 200,0 & 5693,8 & 442,8 & $-8678,0$ \\
\hline
\end{tabular}

Źródło: opracowanie własne na podstawie danych GUS (Rocznik Statystyczny Handlu Zagranicznego: 2007, 2008, 2009, 2010, 2011, 2012, 2013, 2014, 2015, 2016).

Zwiększający się systematycznie z roku na rok import wyrobów z Rosji doprowadził do znaczącego deficytu handlowego w wymianie pomiędzy Polską a Rosją. Czynnikiem decydującym o wielkości importu z Rosji był poziom światowych cen ropy naftowej i gazu ziemnego, dominujących w jego strukturze.

W 2013 r. nastapiła diametralna zmiana - import zmniejszył się o 9,7\%, natomiast eksport wzrósł o 9,3\%. Kryzys w stosunkach politycznych doprowadził w 2014 r. do zmniejszenia wielkości importu i eksportu, przy czym obniżenie importu było mniejsze $(7,3 \%)$ od eksportu $(12,9 \%)$. Wynikało to m.in. ze zmniejszenia popytu wewnętrznego na rynku rosyjskim, który spowodowany był obniżeniem dochodów i dostępności do kredytów, a także dewaluacją waluty rosyjskiej. Spadek popytu na towary importowane 
wzmacniany był prowadzoną przez władze rosyjskie polityką antyimportową. Ponadto, ograniczeniem w prowadzeniu handlu z Rosją był wzrost zagrożenia utratą płynności przez kontrahentów rosyjskich oraz wzrost ryzyka ich niewypłacalności.

W 2015 r. wartość obrotów handlowych obniżyła się w porównaniu do roku poprzedniego o 38,9\% (import o 38,6\%, eksport o 39,5\%), przy jednoczesnym zmniejszeniu się deficytu handlowego o $38 \%$.

Analiza obrotów towarowych pomiędzy Polską a Rosją w latach 2006-2015 w zakresie produktów rolno-spożywczych wykazała, iż wymianę po stronie polskiej charakteryzowała znaczna przewaga udziału eksportu nad importem (Rys. 1). Średni udział artykułów rolno-spożywczych w ogólnym eksporcie do Rosji w analizowanym okresie ukształtował się na poziomie ponad $12 \%$, podczas gdy import z Rosji na poziomie $0,6 \%$.

W latach 2006-2007 udział produktów rolno-spożywczych w eksporcie ogółem zmniejszył się o 3,6\%, natomiast w 2008 r. nastąpił wzrost o 7,6\% w porównaniu do roku poprzedniego. W latach 2009-2011 udział tych towarów w eksporcie ogółem zmniejszył się o 2,5\%, natomiast od 2011 r. do 2013 r. odnotowano wzrost udziału o 2,4\%. W latach 2014-2015 nastapił spadek udziału produktów rolno-spożywczych w eksporcie ogółem o $7,7 \%$.

Handel produktami rolno-spożywczymi wyróżniał się na tle polsko-rosyjskiej wymiany handlowej utrzymującym się saldem dodatnim. Udział importu tych towarów w ogólnej strukturze importu kształtował się na poziomie od 0,32 w 2010 r. do 1,39 w 2015 r.

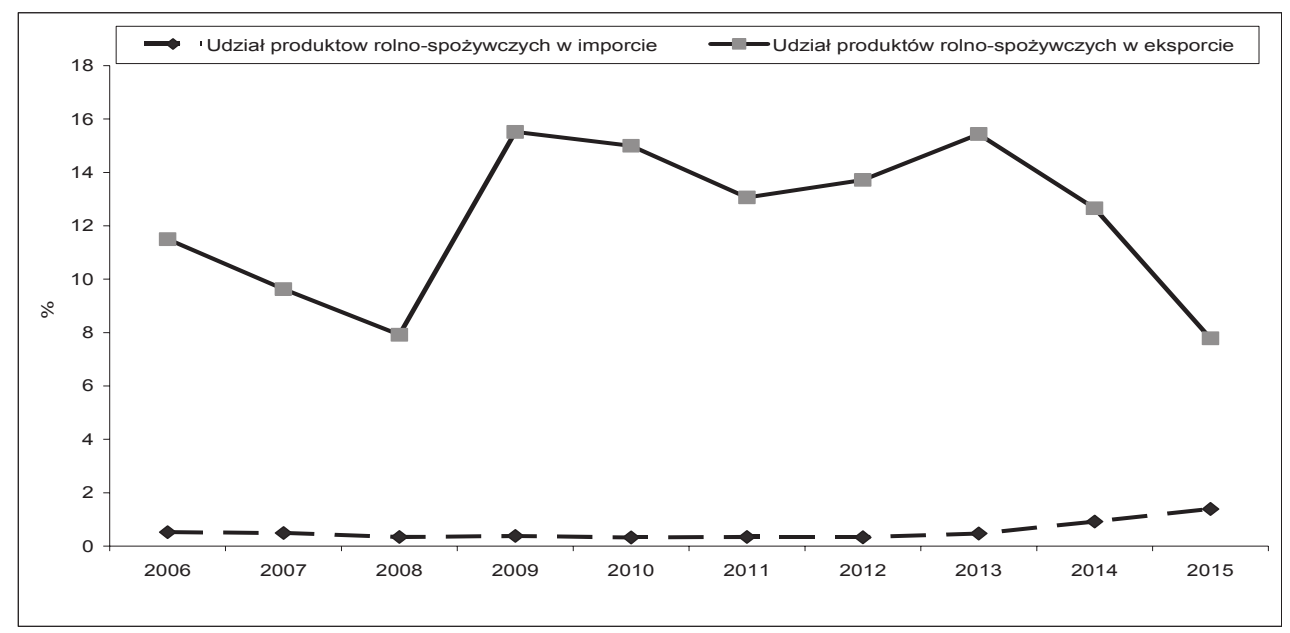

Rys. 1. Udział produktów rolno-spożywczych w ogólnym polskim imporcie i eksporcie z/do Rosji

Fig. 1. Share of agri-food products in overall Polish imports and export from/to Russia

Źródło: opracowanie własne na podstawie danych GUS (Rocznik Statystyczny Handlu Zagranicznego: 2007, 2008, 2009, 2010, 2011, 2012, 2013, 2014, 2015, 2016).

Dynamika polsko-rosyjskiego handlu zagranicznego charakteryzowała się dużą zmiennością (Rys. 2). W 2009 r. odnotowano spadek importu ogółem o 38\% i eksportu ogółem o 44\%, jak również importu produktów rolno-spożywczych o $28 \% \mathrm{w}$ porównaniu do roku poprzedniego. Jednocześnie eksport tych towarów wzrósł o 10\%. W $2010 \mathrm{r}$. w porównaniu do 2009 r., nastąpił wzrost importu ogółem o 42\%, oraz wzrost importu 
produktów rolno-spożywczych z Rosji o $19 \%$. W tym samym okresie, odnotowano wzrost eksportu ogółem o $32 \%$, a towarów rolno-spożywczych o $28 \%$. W 2011 r. w porównaniu do roku poprzedniego, wzrost importu produktów rolno-spożywczych był większy $(47 \%)$ od wzrostu importu ogółem (40\%). W przeciwieństwie do importu, wzrost eksportu towarów rolno-spożywczych był mniejszy (12\%) od wzrostu eksportu ogółem (29\%). W 2012 r. znacznie zmniejszyła się dynamika importu ogółem (10\%) oraz produktów żywnościowych (6\%), natomiast eksport tych towarów do Rosji zwiększył się o $22 \%$. W latach 2013-2014 nastąpił ponowny wzrost importu produktów rolno-spożywczych z Rosji (w 2013 r. o 30\%, a w 2014 r. o 81\%), przy jednoczesnym gwałtownym spadku eksportu tych towarów do Rosji w 2014 r. o 29\%. W 2015 r. odnotowano zarówno spadek importu ogółem (39\%) i eksportu ogółem $(40 \%)$, jak i importu produktów rolnospożywczych (8\%) i eksportu do Rosji tych towarów (63\%).

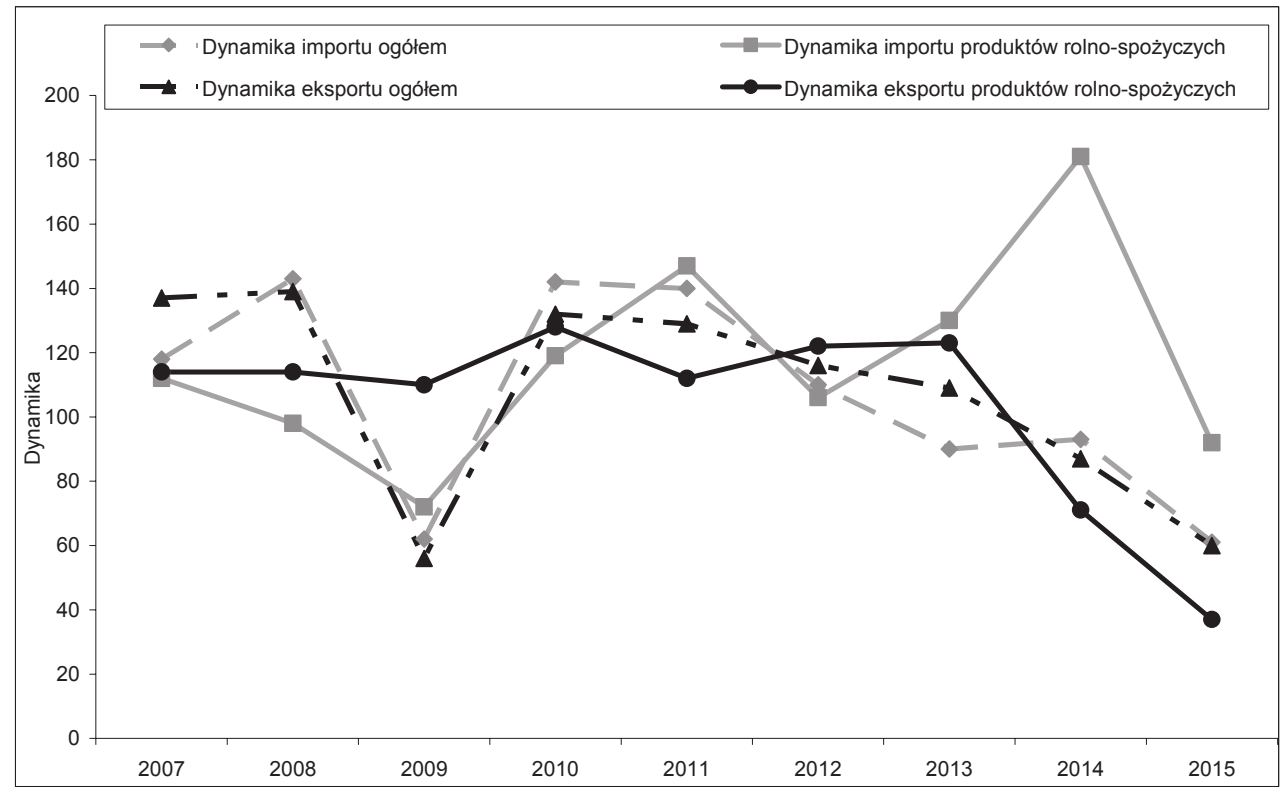

Rys. 2. Dynamika importu i eksportu ogółem oraz produktów rolno-spożywczych (indeksy łańcuchowe)

Fig. 2. The dynamics of imports and exports in general and agri-food products (chain indexes)

Źródło: opracowanie własne na podstawie danych GUS (Rocznik Statystyczny Handlu Zagranicznego: 2007, 2008, 2009, 2010, 2011, 2012, 2013, 2014, 2015, 2016).

Kierunki zmian w polskim handlu zagranicznym z Rosją spowodowane były przede wszystkim kryzysem gospodarczym w Rosji w latach 2008-2009 oraz z wprowadzeniem w 2014 r. ograniczeniami $w$ imporcie towarów rolno-spożywczych z krajów UE. W pierwszej połowie $2014 \mathrm{r}$. rosyjskie służby sanitarne wprowadziły zakaz dostaw polskiej wieprzowiny i produktów mleczarskich, nie wyraziły zgody na dostawę na rynek rosyjski polskich jabłek oraz zgłaszały zastrzeżenia do polskich jaj wylęgowych. Powodem podjęcia tych decyzji były wykryte w Polsce przypadki afrykańskiego pomoru świń oraz rzekome naruszanie rosyjskich norm fitosanitarnych przez polskich producentów. 
Wprowadzenie sankcji gospodarczych przez Stany Zjednoczone Ameryki oraz Unię Europejską na Federację Rosyjską oraz odpowiedź Rosji w postaci ograniczeń importu wielu towarów, rozpoczęły wojnę gospodarczą między strefą euroatlantycką a Rosją (Księżpolski,2014). W odpowiedzi na sankcje Unii Europejskiej, 1 sierpnia 2014 r., Federacja Rosyjska wprowadziła zakaz importu ze Stanów Zjednoczonych Ameryki, państw Unii Europejskiej, Kanady, Australii i Norwegii, następujących towarów:

- mięsa z bydła - świeżego, schłodzonego i zamrożonego,

- mięsa ze świń - świeżego, schłodzonego i zamrożonego,

- mięsa i podrobów jadalnych z drobiu - świeżych, schłodzonych i zamrożonych,

- mięsa solonego, w solance, suszonego i wędzonego,

- $\quad$ ryb żywych (z wyjątkiem wylęgu łososia atlantyckiego i pstrąga),

- ryb, skorupiaków i mięczaków (z wyjątkiem narybku ostryg i małż),

- mleka i produktów mlecznych, z wyjątkiem mleka bezlaktozowego i bezlaktozowych produktów mlecznych wykorzystywanych dla dietetycznego żywienia leczniczego,

- warzyw, jadalnych korzeni i bulw,

- owoców i orzechów świeżych,

- kiełbasy i podobnych wyrobów z mięsa, podrobów lub krwi oraz przetworów żywnościowych na bazie tych wyrobów,

- $\quad$ spożywczych lub gotowych produktów,

- $\quad$ spożywczych lub gotowych produktów wytworzonych według technologii produkcji sera i zawierających $1,5 \%$ lub więcej thuszczu mlecznego.

We współpracy z Federacją Rosyjską obowiązują dodatkowe wymogi i ograniczenia (Ograniczenia importu Federacji Rosyjskiej, 2017):

- od lutego 2014 r. zakaz wwozu z Polski do Rosji mięsa wieprzowego (w związku $\mathrm{z}$ afrykańskim pomorem świń - ASF),

- od 1.08.2014 r. ograniczenia na wwóz z Polski do Rosji poprzez kraje trzecie jabłek, gruszek, pigwy, moreli, wiśni i czereśni, brzoskwiń, nektaryn, śliwek i owoców tarniny, a także świeżych lub schłodzonych warzyw: kapusty i jadalnych kapust, kalafiorów, kalarepy,

- od 6.10.2014 r. embargo na reeksport produktów pochodzenia roślinnego oraz nasion przez terytorium Polski,

- $\quad$ od 20.02.2015 r. zakaz importu z Polski produktów serowych i seropodobnych.

W latach 2006-2015 wartość importu produktów rolno-spożywczych z Rosji wzrosła o prawie 3,2 razy (z 62776 tys. USD do 199986 tys. USD). W analogicznym okresie wartość polskiego eksportu tych towarów do Rosji wzrosła ponad 2,5 razy (z 541602 tys. USD do 1357297 tys. USD).

Wartość importu i eksportu do Rosji w latach 2006-2015 była zależna od kategorii produktów rolno-spożywczych (tab. 2). Największy wzrost importu z Rosji odnotowano w latach 2011-2012 r. w kategorii produkty pochodzenia roślinnego (234\%-202\%). W 2014 r. w przeciwieństwie do eksportu, nastąpił wzrost importu z Rosji produktów pochodzenia roślinnego $(56 \%)$ oraz zwierząt i produktów pochodzenia zwierzęcego (29\%). W 2015 r. import produktów pochodzenia roślinnego wzrósł o 34\%, natomiast zwierząt żywych i produktów pochodzenia zwierzęcego zmniejszył się jedynie o $5 \%$.

Do 2008 r. eksport produktów pochodzenia roślinnego wzrastał we wszystkich kategoriach, w 2009 r. odnotowano wzrost jedynie w kategorii produktów pochodzenia roślinnego (113\%). Spadek eksportu nastapił na skutek kryzysu gospodarczego w Rosji oraz jego konsekwencji. 
Zmiany w polskim handlu zagranicznym produktami rolno-spożywczymi z Federacja Rosyjskq ... 31

Tabela 2. Wartość importu i eksportu produktów rolno-spożywczych z Rosją według kategorii produktów

Table 2. The value of import and export of agri-food products with Russia by product category

\begin{tabular}{|c|c|c|c|c|c|c|c|c|c|c|}
\hline \multirow{2}{*}{ Sekcje CN } & \multicolumn{10}{|c|}{$\begin{array}{c}\text { Wartość importu i eksportu produktów rolno-spożywczych z Rosją według kategorii produktów } \\
\text { [tys. USD] }\end{array}$} \\
\hline & 2006 & 2007 & 2008 & 2009 & 2010 & 2011 & 2012 & 2013 & 2014 & 2015 \\
\hline \multicolumn{11}{|c|}{ Import } \\
\hline $\begin{array}{l}\text { Zwierzęta } \\
\text { żywe, } \\
\text { produkty } \\
\text { pochodzenia } \\
\text { zwierzęcego }\end{array}$ & 54209 & 55511 & 45281 & 27338 & 40813 & 48741 & 39615 & 54058 & 69859 & 66218 \\
\hline $\begin{array}{l}\text { Produkty } \\
\text { pochodzenia } \\
\text { roślinnego }\end{array}$ & 5101 & 4993 & 6570 & 2369 & 2315 & 7741 & 23398 & 21140 & 33080 & 44348 \\
\hline $\begin{array}{l}\text { Thuszcze } \\
\text { i oleje }\end{array}$ & 67 & 3908 & 9782 & 12015 & 5473 & 11085 & 4681 & 6456 & 4498 & 4665 \\
\hline $\begin{array}{l}\text { Przetwory } \\
\text { spożywcze }\end{array}$ & 3399 & 5671 & 7317 & 7583 & 10076 & 18629 & 23940 & 37798 & 108931 & 84755 \\
\hline \multicolumn{11}{|c|}{ Eksport } \\
\hline $\begin{array}{l}\text { Zwierzęta } \\
\text { żywe, } \\
\text { produkty } \\
\text { pochodzenia } \\
\text { zwierzęcego }\end{array}$ & 86549 & 84614 & 113632 & 103965 & 175387 & 182184 & 262403 & 428271 & 179563 & 15201 \\
\hline $\begin{array}{l}\text { Produkty } \\
\text { pochodzenia } \\
\text { roślinnego }\end{array}$ & 97445 & 128589 & 153255 & 326436 & 427207 & 495332 & 643544 & 742358 & 458181 & 65956 \\
\hline $\begin{array}{l}\text { Thuszcze } \\
\text { i oleje }\end{array}$ & 784 & 415 & 448 & 396 & 2574 & 5371 & 5908 & 6251 & 7478 & 7362 \\
\hline $\begin{array}{l}\text { Przetwory } \\
\text { spożywcze }\end{array}$ & 356824 & 405969 & 438909 & 347467 & 387351 & 431531 & 445442 & 491809 & 547038 & 354291 \\
\hline
\end{tabular}

Źródło: opracowanie własne na podstawie danych GUS (Rocznik Statystyczny Handlu Zagranicznego: 2007, 2008, 2009, 2010, 2011, 2012, 2013, 2014, 2015, 2016).

W latach 2010-2013 odnotowano ponowny wzrost eksportu do Rosji we wszystkich kategoriach produktów, największa dynamika dotyczyła kategorii: zwierzęta żywe i produkty pochodzenia zwierzęcego oraz produkty pochodzenia roślinnego. W $2014 \mathrm{r}$. wzrost eksportu wystapił w kategoriach: tłuszcze i oleje (20\%) oraz przetwory spożywcze (11\%). W 2015 r. odnotowano spadek eksportu we wszystkich kategoriach, największy w kategorii zwierzęta żywe i produkty pochodzenia zwierzęcego (92\%) oraz produkty pochodzenia roślinnego (86\%). Spadek polskiego eksportu był przede wszystkim skutkiem rosyjskiego embargo na import towarów z krajów UE.

Analiza wymiany handlowej na niższym poziomie agregacji w latach 2011-2015 wykazała znaczne różnice udziału importu i eksportu towarów rolno-spożywczych z/do Rosji w ogólnym polskim imporcie i eksporcie (tab. 3). W imporcie tych produktów z Rosji dominowały zboża niemielone (26,2\% w 2012 r., 18,2\% w 2015 r.). Drugą pod względem udziału grupą towarową były ryby świeże, jednak ich udział wynosił jedynie 3,8\% w $2015 \mathrm{r}$. 
Tabela 3. Udział importu i eksportu produktów rolno-spożywczych z/do Rosji w ogólnym polskim imporcie i eksporcie w latach 2011-2015

Table 3. Share of imports and exports of agri-food products from / to Russia in total Polish imports and exports in 2011-2015

\begin{tabular}{|c|c|c|c|c|c|c|c|c|c|c|}
\hline \multirow[b]{3}{*}{ Wyszczególnienie } & \multicolumn{10}{|c|}{ Udział importu i eksportu [\%] } \\
\hline & \multicolumn{2}{|c|}{2011} & \multicolumn{2}{|c|}{2012} & \multicolumn{2}{|c|}{2013} & \multicolumn{2}{|c|}{2014} & \multicolumn{2}{|c|}{2015} \\
\hline & 离 & $\begin{array}{l}\frac{1}{0} \\
\frac{0}{0} \\
\frac{0}{0}\end{array}$ & $\begin{array}{l}\stackrel{\Xi}{0} \\
\stackrel{0}{\Xi}\end{array}$ & $\begin{array}{l}\frac{5}{0} \\
\frac{0}{0} \\
\frac{0}{0}\end{array}$ & : & $\begin{array}{l}\frac{5}{0} \\
\frac{0}{0} \\
\frac{0}{0}\end{array}$ & : & $\begin{array}{l}\frac{5}{0} \\
\frac{0}{3} \\
\frac{0}{0}\end{array}$ & $\begin{array}{l}\stackrel{\Xi}{0} \\
\stackrel{0}{\Xi}\end{array}$ & $\begin{array}{l}\frac{\pi}{0} \\
\frac{0}{0} \\
\frac{n}{0}\end{array}$ \\
\hline zwierzęta żywe & - & 9,4 & - & 7,6 & - & 8,0 & - & 7,7 & - & 7,7 \\
\hline $\begin{array}{l}\text { mięso wołowe świeże, schłodzone lub } \\
\text { zamrożone }\end{array}$ & - & 2,3 & - & 3,8 & - & 3,2 & - & 1,7 & - & - \\
\hline $\begin{array}{l}\text { mięso i jadalne podroby świeże, } \\
\text { schłodzone lub zamrożone (bez } \\
\text { wołowego) }\end{array}$ & - & 2,0 & - & 2,9 & - & 5,2 & - & 0,5 & - & - \\
\hline mięso i podroby jadalne pozostałe & - & 1,2 & - & 1,4 & - & 2,7 & - & 1,2 & - & 0,2 \\
\hline mleko i śmietana & - & 0,9 & - & 1,1 & - & 2,9 & - & 1,5 & - & - \\
\hline masło & - & 5,6 & - & 4,6 & - & 7,3 & - & 6,4 & - & - \\
\hline ser i twaróg & - & 7,6 & - & 12,9 & - & 15,6 & - & 10,5 & - & 0,1 \\
\hline jaja świeże & - & 1,3 & - & 0,7 & - & 1,1 & - & 0,8 & - & - \\
\hline ryby świeże & 3,3 & - & 2,7 & - & 2,6 & - & 3,3 & - & 3,8 & - \\
\hline zboża niemielone & 3,0 & - & 26,2 & - & 3,8 & - & 8,4 & - & 18,2 & - \\
\hline przetwory zbożowe i przetwory z mąki & - & 3,1 & - & 3,8 & - & 4,2 & - & 5,6 & - & 3,6 \\
\hline warzywa świeże, schłodzone, zamrożone & - & 18,6 & - & 20,2 & 0,1 & 19,6 & - & 12,4 & - & - \\
\hline warzywa, korzenie, bulwy przetworzone & - & 15,6 & 0,4 & 14,3 & 0,7 & 14,7 & 0,6 & 16,4 & 0,8 & 12,0 \\
\hline owoce i orzechy, świeże lub suszone & - & 41,8 & - & 43,1 & - & 43,4 & - & 28,8 & - & - \\
\hline $\begin{array}{l}\text { owoce zakonserwowane i przetwory } \\
\text { owocowe }\end{array}$ & - & 8,4 & - & 8,1 & - & 7,4 & - & 5,1 & 0,7 & 2,1 \\
\hline soki owocowe i warzywne & - & 2,7 & - & 3,4 & - & 3,6 & - & 6,1 & - & 14,9 \\
\hline cukier, melasa i miód & - & 1,5 & - & 3,7 & - & 2,6 & - & 2,4 & - & 3,7 \\
\hline wyroby cukiernicze & 0,8 & 5,0 & 0,6 & 4,1 & 0,8 & 4,1 & 0,7 & 3,6 & 1,1 & 3,1 \\
\hline kawa i jej pochodne & - & 5,7 & - & 4,9 & - & 3,9 & - & 2,3 & - & 2,5 \\
\hline kakao & - & 14,8 & - & 14,3 & - & 13,9 & - & 8,0 & - & 8,5 \\
\hline $\begin{array}{l}\text { czekolada i inne produkty zawierające } \\
\text { kakao }\end{array}$ & - & 10,5 & - & 8,6 & - & 4,3 & - & 4,4 & 0,3 & 3,2 \\
\hline herbata & - & 2,4 & - & 2,9 & - & 2,5 & - & 2,9 & - & 1,8 \\
\hline przyprawy & - & 26,7 & - & 25,3 & 1,5 & 26,7 & 1,8 & 24,8 & - & 18,0 \\
\hline $\begin{array}{l}\text { produkty i przetwory spożywcze, nie } \\
\text { wymienione }\end{array}$ & 0,3 & 5,7 & 0,4 & 6,3 & 0,5 & 7,2 & 0,4 & 6,7 & 0,4 & 3,4 \\
\hline napoje bezalkoholowe & - & 2,6 & - & 1,4 & - & 1,8 & - & 1,3 & - & 1,0 \\
\hline napoje alkoholowe & 0,2 & 1,2 & 0,3 & 1,4 & 0,2 & 1,1 & 0,4 & 1,1 & 0,3 & 0,9 \\
\hline tytoń nieprzetworzony & - & 8,3 & - & 19,3 & - & 18,9 & - & 17,9 & - & 5,6 \\
\hline oleje i tłuszcze zwierzęce & - & 19,0 & - & 17,1 & - & 20,3 & - & 6,5 & - & 6,3 \\
\hline $\begin{array}{l}\text { oleje i tłuszcze roślinne surowe, } \\
\text { rafinowane }\end{array}$ & 3,1 & - & 1,3 & - & 2,1 & 0,3 & 0,9 & 0,6 & 1,2 & 0,5 \\
\hline
\end{tabular}

Źródło: opracowanie własne na podstawie danych GUS (Rocznik Statystyczny Handlu Zagranicznego: 2012, 2013, 2014, 2015, 2016). 
Struktura towarowa polskiego eksportu produktów rolno-spożywczych do Rosji była bardzo zróżnicowana. Dominowały w niej owoce i orzechy świeże lub suszone $(41,8 \%$ w 2011 r., 28,9\% w 2012 r., w 2015 r. nie odnotowano eksportu tych produktów), przyprawy (26,7\% w 2011 r., $18 \%$ w 2015 r.) oraz oleje i thuszcze zwierzęce (analogicznie 19\%-6,3\%). Oprócz wyżej wymienionych grup, w latach 2011-2014 na wysokim poziomie utrzymywał się udział: warzyw i bulw przetworzonych (15,5\%-16,4\%), warzyw świeżych, schłodzonych i zamrożonych (18,6\%-12,4\%), tytoniu nieprzetworzonego $(8,3 \%-17,9 \%)$, sera i twarogu (7,6\%-10,5\%) oraz kakao (14,8\%-8\%). W latach 2011-2014 wymienione towary należały do najważniejszych $\mathrm{w}$ polskim eksporcie produktów rolno-spożywczych do Rosji. W 2015 r. odnotowano gwałtowny spadek udziału w eksporcie wszystkich wymienionych grup za wyjątkiem kakao, którego udział nieznacznie się zwiększył ( $8 \%$ w 2014 r., 8,5\% w 2015 r.). W pozostałych grupach towarowych zachodziły również zmiany, zanotowano znaczny spadek udziału eksportu, np. warzyw świeżych, schłodzonych i zamrożonych (12,4\% w 2014 r., $0 \%$ w 2015 r.), masła (6,4\% w 2014 r., $0 \%$ w 2015 r.), sera i twarogu $(10,5 \%$ w 2014 r., $0,1 \%$ w 2015 r.) oraz produktów i przetworów spożywczych (6,7\% w 2014 r., 3,4\% w 2015 r.).

W latach 2011-2015 odnotowano wzrost udziału w eksporcie jedynie soków owocowych i warzywnych $(2,7 \%$ w 2011 r., 14,9\% w 2015 r.) oraz cukru, melasy i miodu (odpowiednio 1,5\%-3,7\%).

Zmiany w strukturze eksportu były przede wszystkim skutkiem ograniczeń w imporcie do Rosji towarów rolno-spożywczych, a także dewaluacji rubla, spadku dochodów i zmniejszenia się popytu wewnętrznego na rynku rosyjskim. Nie bez znaczenia była także prowadzona przez władze rosyjskie polityka antyimportowa, prowadząca do zmniejszenia popytu na towary importowane.

Wraz z reorientacją w strukturze handlu zagranicznego produktami rolno-spożywczych w latach 2011-2015, ulegała zmianie dynamika importu i eksportu tych towarów (tab. 4). Największy wzrost importu z Rosji dotyczył takich towarów jak: zboża niemielone, warzywa przetworzone, ryby świeże, wyroby cukiernicze, przetwory spożywcze, napoje alkoholowe oraz oleje i thuszcze roślinne. Analiza porównawcza importu w 2011 r. do importu w 2015 r. wykazała dodatnią dynamikę w następujących grupach: zboża niemielone (355\%), wyroby cukiernicze (48\%), napoje alkoholowe (45\%), przetwory spożywcze (40\%) oraz ryby świeże (33\%). Ujemna dynamika importu z Rosji dotyczyła jedynie olejów i thuszczy roślinnych.

Do czasu wprowadzenia przez Rosję embarga na produkty rolno-spożywcze z krajów UE, Polska eksportowała coraz więcej żywności do Rosji. W latach 2012-2013 wzrost dynamiki eksportu do Rosji dotyczył większości grup towarowych (za wyjątkiem olei i tłuszczy roślinnych, kawy i jej pochodnych oraz czekolady). Największa zwyżka eksportu w 2012 r. obejmowała: cukier, melasę i miód (249\%), tytoń nieprzetworzony (120\%), ser i twaróg $(79 \%)$, mięso wołowe $(68 \%)$, mięso i jadalne podroby świeże, schłodzone lub zamrożone bez mięsa wołowego (61\%) oraz owoce i orzechy $(51 \%)$. W 2013 r. największy wzrost eksportu nastapił w następujących grupach produktów: mięso i jadalne podroby świeże, schłodzone lub zamrożone bez mięsa wołowego (109\%), mięso i podroby jadalne pozostałe (136\%), mleko i śmietana (224\%), masło (118\%).

W 2014 r. wzrost eksportu dotyczył jedenastu grup produktów: olejów i thuszczy roślinnych $(117 \%)$, przetworów zbożowych $(60 \%)$, soków owocowych i warzywnych $(41 \%)$, herbaty (33\%), przypraw (18\%), warzyw przetworzonych $(17 \%)$, czekolady $(13 \%)$, napoi alkoholowych (9\%), przetworów spożywczych (8\%), wyrobów cukierniczych (7\%) oraz tytoniu nieprzetworzonego $(2 \%)$. 


\section{I.M. Batyk}

Tabela 4. Dynamika importu i eksportu produktów rolno-spożywczych w latach 2012-2015

Table 4. The dynamics of groups in import and export of agri-food products in 2011-2015

\begin{tabular}{|c|c|c|c|c|c|c|c|c|c|c|}
\hline \multirow{3}{*}{ Wyszczególnienie } & \multicolumn{8}{|c|}{ Dynamika importu i eksportu, rok poprzedni $=100$} & \multirow{2}{*}{\multicolumn{2}{|c|}{$\begin{array}{l}\text { Dynamika } \\
2011=100 \\
2015 / 2011\end{array}$}} \\
\hline & \multicolumn{2}{|c|}{2012} & \multicolumn{2}{|c|}{2013} & \multicolumn{2}{|c|}{2014} & \multicolumn{2}{|c|}{2015} & & \\
\hline & : & $\begin{array}{l}\frac{1}{0} \\
\frac{0}{0} \\
\frac{y}{0}\end{array}$ & 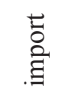 & $\begin{array}{l}\frac{5}{0} \\
\frac{0}{0} \\
\frac{0}{0}\end{array}$ & : & $\begin{array}{l}\frac{5}{0} \\
\frac{0}{0} \\
\frac{0}{0}\end{array}$ & 苛 & $\begin{array}{l}\frac{1}{0} \\
\frac{0}{2} \\
\frac{y}{2}\end{array}$ & .气 & $\begin{array}{l}\frac{\hbar}{0} \\
\frac{0}{2} \\
\frac{3}{0}\end{array}$ \\
\hline zwierzęta żywe & - & 82 & - & 100 & - & 83 & - & 79 & - & 54 \\
\hline $\begin{array}{l}\text { mięso wołowe świeże, schłodzone lub } \\
\text { zamrożone }\end{array}$ & - & 168 & - & 90 & - & 54 & - & - & - & - \\
\hline $\begin{array}{l}\text { mięso i jadalne podroby świeże, } \\
\text { schłodzone lub zamrożone (bez mięsa } \\
\text { wołowego) }\end{array}$ & - & 161 & - & 209 & - & 10 & - & - & - & - \\
\hline mięso i podroby jadalne pozostałe & - & 141 & - & 236 & - & 45 & - & 16 & -- & 12 \\
\hline mleko i śmietana & - & 113 & - & 324 & - & 63 & - & - & - & - \\
\hline masło & - & 52 & - & 218 & - & 89 & - & - & - & - \\
\hline ser i twaróg & - & 179 & - & 157 & - & 65 & - & 0,7 & - & 1 \\
\hline jaja świeże & - & 82 & - & 145 & - & 69 & - & - & - & - \\
\hline ryby świeże & 78 & - & 125 & - & 135 & - & 101 & - & 133 & - \\
\hline zboża niemielone & 935 & - & 645 & - & 275 & - & 194 & - & 455 & - \\
\hline przetwory zbożowe i przetwory z mąki & - & 119 & - & 132 & - & 160 & - & 65 & - & 164 \\
\hline $\begin{array}{l}\text { warzywa świeże, schłodzone, } \\
\text { zamrożone }\end{array}$ & - & 116 & - & 110 & - & 62 & - & 0,6 & - & 0,5 \\
\hline $\begin{array}{l}\text { warzywa, korzenie, bulwy } \\
\text { przetworzone }\end{array}$ & - & 98 & 221 & 122 & 91 & 117 & 127 & 66 & - & 93 \\
\hline owoce i orzechy, świeże lub suszone & - & 151 & - & 120 & - & 56 & - & - & - & - \\
\hline $\begin{array}{l}\text { owoce zakonserwowane i przetwory } \\
\text { owocowe }\end{array}$ & - & & - & 93 & - & 70 & - & 38 & - & 26 \\
\hline soki owocowe i warzywne & - & 142 & - & 114 & - & 141 & - & 75 & - & 170 \\
\hline cukier, melasa i miód & - & 349 & - & 63 & - & 76 & - & 111 & - & 187 \\
\hline wyroby cukiernicze & 74 & 92 & 153 & 122 & 98 & 107 & 133 & 81 & 148 & 96 \\
\hline kawa i jej pochodne & - & 89 & - & 78 & - & 77 & - & 111 & - & 59 \\
\hline kakao & - & 92 & - & 107 & - & 62 & - & 109 & - & 67 \\
\hline $\begin{array}{l}\text { czekolada i inne produkty zawierające } \\
\text { kakao }\end{array}$ & - & 84 & - & 63 & - & 113 & - & 73 & - & 43 \\
\hline herbata & - & 146 & - & 105 & - & 133 & - & 49 & - & 98 \\
\hline przyprawy & - & 114 & - & 131 & 135 & 118 & - & 63 & - & 112 \\
\hline $\begin{array}{l}\text { produkty i przetwory spożywcze, nie } \\
\text { wymienione }\end{array}$ & 155 & 113 & 132 & 141 & 84 & 108 & 81 & 46 & 140 & 80 \\
\hline napoje bezalkoholowe & - & 53 & - & 167 & - & 90 & - & 78 & - & 62 \\
\hline napoje alkoholowe & 134 & 122 & 86 & 97 & 189 & 109 & 67 & 74 & 145 & 95 \\
\hline tytoń nieprzetworzony & - & 220 & - & 139 & - & 102 & - & 33 & - & 103 \\
\hline oleje i tłuszcze zwierzęce & - & 120 & - & 121 & - & 24 & - & 70 & - & 25 \\
\hline $\begin{array}{l}\text { oleje i tłuszcze roślinne surowe, } \\
\text { rafinowane }\end{array}$ & 42 & - & 134 & - & 48 & 217 & 106 & 71 & 29 & - \\
\hline
\end{tabular}

Źródło: opracowanie własne na podstawie danych GUS (Rocznik Statystyczny Handlu Zagranicznego: 2012, 2013, 2014, 2015, 2016). 
W 2015 r. w porównaniu do roku poprzedniego, odnotowano wzrost eksportu do Rosji trzech grup towarów: cukru, melasy, miodu (11\%), kawy i jej pochodnych $(11 \%)$ oraz kakao (9\%). Eksport do Rosji pozostałych grup towarów uległ zmniejszeniu. Analiza porównawcza eksportu w 2011 r. do eksportu w 2015 r. wykazała dynamikę w następujących grupach: cukier, melasa i miód $(87 \%)$, soki owocowe i warzywne $(70 \%)$, przetwory zbożowe $(64 \%)$, przyprawy $(12 \%)$ oraz tytoń nieprzetworzony $(3 \%)$.

\section{Podsumowanie}

Znaczny wzrost importu z Rosji, głównie produktów mineralnych oraz wprowadzone przez Rosje ograniczenia $w$ imporcie produktów rolno-spożywczych z krajów UE, spowodowały zwiększenie strukturalnego deficytu Polski w handlu z Rosją. Utrzymujące się ujemne saldo obrotów handlowych świadczy o pogłębiającym się kryzysie w stosunkach handlowych oraz istotnym oddziaływaniu sytuacji geopolitycznej na współpracę gospodarczą.

Decydującym czynnikiem wpływającym na wielkość polskiego importu z Rosji w latach 2006-2015 był poziom światowych cen ropy naftowej i gazu ziemnego, dominujących $\mathrm{w}$ jego strukturze. Wpływ na warunki importu $\mathrm{z}$ Rosji miało również włączenie Polski do jednolitego rynku europejskiego, co oznaczało, że towary rosyjskie musiały spełniać, często restrykcyjne wymogi. Ponadto, objęcie Polski wspólną polityką rolną związane było z obowiązkiem uzyskania przez rosyjskich eksporterów pozwoleń na przywóz niektórych towarów rolno-spożywczych do naszego kraju.

Istotne znaczenie dla polskiego eksportu do Rosji miało przystapienie Polski do UE, które wpłynęło na zmianę postrzegania Polski jako partnera gospodarczego. Uległ zmianie wizerunek polskich firm i produktów, co wywołało pozytywny efekt psychologiczny. Polskie towary zaczęły być uznawane w Rosji za jakościowo równie dobre jak pochodzące z innych krajów Wspólnoty. Czynnikiem sprzyjającym rozwojowi polskiego eksportu w latach 2010-2013 była poprawa koniunktury gospodarczej w Rosji, spowodowana rosnącymi cenami surowców energetycznych eksportowanych przez ten kraj. Sytuacji gospodarczej towarzyszył wzrost zapotrzebowania na towary, zaspokajany częściowo importem. Popyt wewnętrzny wzmacniała aprecjacja rubla, zwiększona dostępność do kredytów oraz niska konkurencyjność produkcji rodzimej.

Ograniczenia $\mathrm{w}$ imporcie towarów rolno-spożywczych $\mathrm{z}$ krajów UE wprowadzone przez Rosję w 2014 r., w znacznym stopniu wpłynęły na spadek dynamiki polskiego eksportu tych towarów do Rosji. Ponadto, warunki polityczno-gospodarcze zniechęcały firmy polskie do prowadzenia handlu z Rosją. Obawy przedsiębiorców polskich dotyczyły permanentnych zmian przepisów weterynaryjnych i fitosanitarnych wprowadzanych przez rosyjskie organy kontrolne oraz zagrożeń związanych z utratą płynności finansowej przez kontrahentów rosyjskich i wzrostu ryzyka ich niewypłacalności. Od 2014 r., na skutek spadku dochodów i dostępności kredytów, a także dewaluacji rubla, zmniejszył się popyt wewnętrzny na rynku rosyjskim. Dodatkowo popyt na dobra importowane uległ osłabieniu pod wpływem prowadzonej przez władze rosyjskie polityki antyimportowej.

Niezależnie od sytuacji gospodarczej, na polsko-rosyjskie stosunki handlowe silnie oddziaływał wzmożony protekcjonizm w Rosji. W okresie kryzysu gospodarczego służył on ochronie rodzimego przemysłu lub realizacji polityki antykryzysowej. Protekcjonizm 
odczuwany był także w okresie dobrej koniunktury, służył wówczas realizacji celów polityki przemysłowej i zapewnieniu samowystarczalności żywieniowej kraju.

Do poprawy polsko-rosyjskich relacji gospodarczych i handlowych konieczna jest akceptacja przez Rosję norm unijnych na produkcję oraz certyfikację weterynaryjną i fitosanitarną produktów rolno-spożywczych. Dostosowanie norm stanowi warunek niezbędny dla rozwoju efektywnej wzajemnej współpracy. Jak do tej pory nie został dokonany praktycznie żaden istoty postęp $\mathrm{w}$ tej kwestii. Aktywność na rzecz zbliżania ustawodawstwa i standardów zależna jest od decyzji politycznych i wydaje się, że deklaracje o wzajemnej współpracy jawią się jako niewystarczające.

W perspektywie dynamicznie zachodzących zmian gospodarczych, warto skierować wysiłki zarówno producentów, jak i państwa na penetrację rynków światowych, prowadzącą do dywersyfikacji polskiego importu i eksportu. Warto również monitorować polski handel zagraniczny z Rosją oraz zjawisko handlu przygranicznego, odbywającego się na pograniczu polsko-rosyjskim. Współpraca transgraniczna jest wielkim wyzwaniem, które dotyczy nie tylko krajów i regionów przygranicznych, ale także poszczególnych podmiotów działających na rynkach przygranicznych.

\section{Literatura}

Batyk, I.M. (2014). Perspektywy rozwoju eksportu polskich produktów rolno-spożywczych do Rosji (Prospects for The development of export of Polish agri-food products to Russia). ZN SGGW Warszawie Problemy Rolnictwa Światowego, 14(3), 7-14.

Błaszczuk-Zawiła, M. (2014). Polsko-rosyjska wymiana handlowa w okresie członkowstwa Polski w Unii Europejskiej (Polish-Russian Trade during The First Ten Years of Poland's Membership in the European Union). Unia Europejska.pl, 3(226), 16-29.

Czyżowicz, W. (2009). Polityka i prawo celne UE a obrót towarowy z sąsiadami ze wschodu (EU customs policy and customs law and trade in goods with neighbors from the east). W: M, A. Zdanowicz, Doliwa-Klepacka (red.) Wybrane aspekty wpływu członkostwa państw Europy Środkowo-Wschodniej w Unii Europejskiej na stosunki ze wschodnimi państwami ościennymi. Białystok: Temida 2.

Gospodarcze i społeczne efekty członkowstwa Polski w Unii Europejskiej. Notatka w związku jedenastą rocznicą przystapienia Polski do UE (Economic and social effects of Poland's membership in the European Union. Note in connection with the eleventh anniversary of Poland's accession to the EU). (2014). Warszawa: Ministerstwo Spraw Zagranicznych. Pobrane 30 października 2017 z: http:/www.msz.gov.pl/resource/ 26c005f4-b73e-4402-bb32-8b10c1b42a4c:JCR

Grant, J.H., Lambert, D.M. (2008). Do Regional Trade Agreements Increase Members' Agricultural Trade? American Journal of Agricultural Economics, 90(3), 765-782.

Księżpolski, K.M. (2014). Wyzwania dla bezpieczeństwa ekonomicznego Polski w XXI wieku (Challenges for Poland's economic security in the 21 st century). W: K. Czornik, M. Lakomy (red.) Dylematy polityki bezpieczeństwa Polski na początku drugiej dekady XXI wieku. Katowice: Regionalny Ośrodek Debaty Międzynarodowej, 319-333.

McCalla, A.F. (1993). Agricultural Trade Liberalization: The Ever-Elusive Grail. American Journal of Agricultural Economics, 75(5), 1102-1112.

Ograniczenia importu Federacji Rosyjskiej (Restrictions on the import of the Russian Federation). Pobrane 8 sierpnia 2016 r. z: https://russia.trade.gov.pl/pl/rosja/analizy-rynkowe/144081,ograniczenia-importufederacji-rosyjskiej.html.

Pasińska, D. (2017). Zmiany w polskim handlu zagranicznym produktami wieprzowymi po wprowadzeniu przez Rosję embarga (Changes in Polish Foreign Trade in Pork Products after the Introduction of The Russian Embargo). ZN SGGW Problemy Rolnictwa Światowego, 17(2), 186-198.

Powiązania gospodarki polskiej z Rosją, Ukrainą i Białorusią - wybrane aspekty (Associations of the Polish economy with Russia, Ukraine and Belarus - selected aspects). GUS, (2015). 
Wiśniewska, I. (2011). Embargo w rosyjskiej polityce handlowej - taktyka bez strategii (Embargo in Russian trade policy - tactics without a strategy). Pobrane 23 stycznia 2018 r. z: https://www.osw.waw.pl/pl/publikacje/ analizy/2011-07-13/embargo-w-rosyjskiej-polityce-handlowejtaktyka-bez-strategii.

Główny Urząd Statystyczny (2007). Rocznik Statystyczny Handlu Zagranicznego (Yearbook of Foreign Trade Statistics of Poland). Warszawa.

Główny Urząd Statystyczny (2008). Rocznik Statystyczny Handlu Zagranicznego (Yearbook of Foreign Trade Statistics of Poland). Warszawa.

Główny Urząd Statystyczny (2009). Rocznik Statystyczny Handlu Zagranicznego (Yearbook of Foreign Trade Statistics of Poland). Warszawa.

Główny Urząd Statystyczny (2010). Rocznik Statystyczny Handlu Zagranicznego (Yearbook of Foreign Trade Statistics of Poland). Warszawa.

Główny Urząd Statystyczny (2011). Rocznik Statystyczny Handlu Zagranicznego (Yearbook of Foreign Trade Statistics of Poland). Warszawa.

Główny Urząd Statystyczny (2012). Rocznik Statystyczny Handlu Zagranicznego (Yearbook of Foreign Trade Statistics of Poland). Warszawa.

Główny Urząd Statystyczny (2013). Rocznik Statystyczny Handlu Zagranicznego (Yearbook of Foreign Trade Statistics of Poland). Warszawa.

Główny Urząd Statystyczny (2014). Rocznik Statystyczny Handlu Zagranicznego (Yearbook of Foreign Trade Statistics of Poland). Warszawa.

Główny Urząd Statystyczny (2015). Rocznik Statystyczny Handlu Zagranicznego (Yearbook of Foreign Trade Statistics of Poland). Warszawa.

Główny Urząd Statystyczny (2016). Rocznik Statystyczny Handlu Zagranicznego (Yearbook of Foreign Trade Statistics of Poland). Warszawa.

Współpraca handlowa Polski z krajami WNP, w szczególności z Rosją, Ukrainą i Białorusią (Poland's trade cooperation with the CIS countries, in particular with Russia, Ukraine and Belarus). (2014). Ministerstwo Gospodarki.

Do cytowania / For citation:

Batyk I.M. (2018). Zmiany w polskim handlu zagranicznym produktami rolno-spożywczymi z Federacją Rosyjską w latach 2006-2015. Problemy Rolnictwa Światowego, 18(1), 23-37; DOI: $10.22630 /$ PRS.2018.18.1.2

Batyk I.M. (2018). Changes in Polish Foreign Trade in Agri-Food Products with the Russian Federation in 2006-2015 (in Polish). Problems of World Agriculture, 18(1), 23-37;

DOI: $10.22630 / P R S .2018 .18 .1 .2$ 